\title{
Nation Branding in Transition Countries: A Multimodal Analysis of Romania and Moldova Tourism Campaigns
}

\section{Bianca-Florentina Cheregi ${ }^{1}$}

\begin{abstract}
The nature of nationhood is changing in the age of globalization, marketization, and mediatization. In this context, the nation is built as a brand with the aim of attracting tourists and increase economic development. A particular case of nation branding is to be found in Romania and Moldova, two countries that started to reposition themselves after the fall of communism. In this context, this paper focuses on a comparative semiotic analysis of two nation branding campaigns initiated by the Romanian and Moldavian Governments: "Discover the Place Where You Feel Reborn" (Romania, 2014) and "Discover the Routes of Life" (Moldova, 2014). In so doing, a multimodal approach (ledema, 2003; Kress \& Van Leeuwen, 1996; Van Leeuwen, 2001) is employed, highlighting the importance of image, sound and text as semiotic resources in the discursive configuration of Romania's and Moldova's nation brands, comparatively. Special attention is given to the analysis of logos, websites and videos, comprising different communication situations used to create meaning in the tourism campaigns. The paper investigates how elements of neoliberal ideology are addressed in two governmental campaigns, comparatively, considering the "marketization of public discourse" (Fairclough, 1993).

Keywords: nation branding, transition countries, multimodal analysis, social semiotics, neoliberal ideology.
\end{abstract}

\section{INTRODUCTION}

In today's digital era, nation branding campaigns use strategies such as usergenerated content or 'crowd-sourcing' in order to encourage citizens to became 'brand ambassadors' of their country. For instance, one example is the 2016 "Call a Swede" tourism campaign that connected callers from all over the

1 Bianca-Florentina Cheregi, Ph.D. Assistant Lecturer, College of Communication and Public Relations, National University of Political Studies and Public Administration, Expoziției St., no. 30A, 012104, Bucharest, Romania, e-mail: bianca.cheregi@comunicare.ro

Received 13 July 2018; Revised 17 September 2018; Accepted 20 September 2018 
world with random Swedes who had signed up to be de facto ambassadors. The initiative was based on citizen participation, giving regular people based in Sweden the opportunity to talk with people from other countries, answering any questions they might have about visiting the country.

As one can see, today's increased use of computer and information technology affects the construction of the nation brand through advertising tourism campaigns. The public's imagination is now shaped though transmedia engagement, which goes beyond the notion of a single content adapted from one media format to another, unfolding "across multiple media platforms, with each new text making a distinctive and valuable contribution to the whole" (Jenkins, 2006, pp. 97-98). For example, the 2010 Tourism Australia campaign, "There's Nothing Like Australia", was a 'crowd-sourcing' initiative encouraging citizens to share photos of their holidays in Australia via social media networks, "claiming to empower them in the construction of a more democratic and authentic image of their country" (Volcic \& Andrejevic, 2016, p. 6).

Nation branding has become an "important yet contested topic in research, attracting an interdisciplinary interest, from areas such as marketing, international public relations, and public diplomacy" (Cheregi, 2018 , p. 17). The term was first mentioned in 1996, by the British brand practitioner Simon Anholt $(2007$, p. 3), who defined it as the practice of building and communicating the country image to the rest of the world, through diplomacy, trading, export, and tourism.

Nation branding should also be understood in the contemporary fake news phenomenon, which puts an emphasis on fabricated content, aiming to generate maximum attention and, therefore, maximum profit. According to Kaneva (2018, p. 6), "nation branding is nothing more than a tool or a technology, which can be used by 'responsible governments' to ensure 'fair, true, powerful, attractive, genuinely useful' representations of their nations."

Drawing on Baudrillard's (2001) post-structuralist media theory we can "see nation brands in a new light, namely, as simulacra which exist within a transnational media system for the creation, circulation and consumption of commodity signs" (Kaneva, 2018, p. 3). The idea of the simulacra in societies leads further to the state of hyper-reality where the distinction between the real and the simulation is not so clear. For Kaneva (2018, p. 10), products of nation branding campaigns are, in fact, simulation nations, understood as "contradictory compendium of signs, flashing through global media circuits, trying to seduce various audiences." We can notice here the semiotic structure of the nation brand, which "presupposes a broader intertextual field to be managed in order to create nation brand recognition and distinction" (Graan, 2016, p. S102). 
One of the most essential functions promoting the country image overseas is to communicate the idea of a nation. In this regard, Szondi (2007, p. 11) argues that branding has had an important role in generating a discussion about identities, mainly because it can help define a particular type of country identity that can be communicated to other nations. Furthermore, the audience must identify itself with the brand, so the citizens should become "brand ambassadors" (Szondi, 2007, p. 19).

There is a relation between nation branding and neoliberal ideology, taking into account the fact that nations are perceived as brands in the age of globalization. This happens because of the capitalist logic, which puts an emphasis on competitive markets. In this context, "neoliberalism is both an approach to government and a defining political movement," using the "market to govern, distributing services and benefits according to the market logic of efficiency, competitiveness, and profitability" (Bockman, 2013, pp. 14-15). In the case of nation branding, the competitive advantage is given by national values, culture, and economic structure. Varga $(2013$, p. 1) develops this idea further, stating that nation branding is "a political marketing strategy that targets external markets to establish and communicate a specific image of national identity."

A particular case of nation branding is to be found in Romania and Moldova, two countries that started to reposition themselves after the fall of communism. In transition countries, nation branding is often mentioned because of the constant need to reconfigure national identity by dissociating from the communist past (Kaneva, 2011).

Moldova and Romania are two countries that share common traditions and folklore, along with the same official language - Romanian and a common name for the monetary unit - the leu. They also share a common history, since in 1918, at the end of World War I, Bessarabia, part of the Principality of Moldovia, united with Transylvania, Bukovina, and the Romanian Old Kingdom. Bessarabia was under Romanian jurisdiction until 1940, when a Soviet ultimatum to give up Bessarabia and Northern Bukovina came along. Russia, and later the Soviet Union did not recognize the Romanian rule over Bessarabia, although it lasted for twenty-two years.

The unification of Romania and Moldova is a popular concept in both countries, that began after the fall of the communist regime in 1989, and the independence of Moldova in 1991. An interesting fact is that "the question of reunification is recurrent in the public sphere of the two countries, often as speculation, both as a goal and a danger" (Academic Dictionaries and Encyclopedias, n.d.). The idea is widespread in Romania and the individuals who advocate the unification are called "unionists," while opponents are known as "Moldovenists." 
Nation branding is seen as a panacea for small and under-developed countries, as a need to enhance the competitive advantage on the global stage (Anholt, 2003; Dinnie, 2008; Olins, 2002; Papadopoulos \& Heslop, 2002). Romania is a post-communist country with a bad image internationally, that is why the nation branding phenomenon has the mission of improving the competitive advantage.

The country image of Romania became "the object of an institutionalization process" (Beciu, 2011, p. 110) starting in 2005. The EU integration process facilitated the orientation towards a neoliberal discourse in promoting the national image overseas.

In Romania, nation branding is a step in the process of discursively constructing the country image as a public issue (Cheregi, 2017, 2018). Moldova is a country at a crossroads, struggling between a pro-Western and pro-Moscow foreign policy orientation (Buduru \& Popa, 2006, p. 171) that is reflected in the country's branding initiatives as well.

In this context, the present study focuses on a comparative semiotic analysis of two nation branding campaigns initiated by the Romanian and Moldavian Governments: Discover the Place Where You Feel Reborn (Romania, 2014) and Discover the Routes of Life (Moldova, 2014). This paper aims to provide a cross-cultural comparison of nation branding in two transition countries that share common traditions and Romanian as a native language. Thus, there is controversy over the national identity of Moldavians, asking whether they constitute a subgroup of Romanians or a separate ethnic group. The controversy is also part of Moldova's political agenda since there are Moldovan politicians that insist on the idea of a Moldovan language.

The next two sections introduce in more detail the theoretical framework, presenting the fields of research in nation branding, and drawing attention to different areas and schools of thought. A multidisciplinary perspective is necessary in order to understand the global phenomenon of nation branding, dwelling upon a semiotic lens to deeply explore the meanings employed in the tourism advertising campaigns. Then, the paper moves forward to a brief overview of nation branding campaigns in Romania and Moldova, comparatively. The methodological tools for analyzing the importance of image, sound and text as semiotic resources in the discursive configuration of Romania's and Moldova's nation brands are presented in-depth. Finally, the discussion views the findings resulting from the social semiotic analysis of the two governmental campaigns, outlining types of national identity discourses and elements of neoliberal ideology employed in the campaigns. 


\section{LITERATURE REVIEW}

\section{Fields of research in nation branding}

Why is nation branding such a debated issue nowadays, in areas such as consultancy, marketing, politics, and media? Nations have always been preoccupied with their image on the international stage, even if the process was not named as "nation branding." Not all researchers agree with the term, considering it imperfect. For Dinnie (2008), a more appropriate term would be "reputation management," "competitive identity" or "public diplomacy," while Surowiec (2012) and Volcic (2012) prefer to use "neoliberal corponationalism" or "commercial nationalism."

There are no universal recipes to promote the nation as a brand. In this regard, there are two forms of manifesting nation branding: countryof-origin-effect, referring to the "made in" products, commercialized on the global marketplace and destination branding, related to promoting a country in order to attract tourists. The country-of-origin effect (COO) concept was first mentioned in 1965 when Schooler (1965) started to study the products' image considering their country-of-origin. He concluded that the prejudices have appeared as an economic and political phenomenon, and people's perception of a nation-state leads to the emergence of stereotypes. Roth and Romeo (1992) argue too that the country image is a perception of a country's products, based on the previous consumers' perceptions about that state's productivity. As a matter of fact, the products' image is biased by the stereotypes about the country-of-origin, and this can impact the economic development of the nation-state.

The touristic brand is strongly connected to the nation brand. In this regard, Crompton $(1979$, p. 18) considers that the country image is, in fact, the sum of beliefs, ideas, and impressions that a person has of a destination. For Kotler, Haider and Rein (1993), the concept of tourism image destination (TID) is more appropriate, being defined as the effect of beliefs, ideas, and impressions that a person has of a destination. Thus, a clear distinction has to be made between destination branding and country branding. Foremost, "the aim of destination branding is to attract visitors and boost tourism (inwards direction), while country branding promotes economic, commercial and political interests at home and abroad" (Szondi, 2007, p. 9). The country image is presented through elements such as beautiful landscapes, monumental buildings, museums, local cuisine, folk costumes, music, or national dances.

In the last few decades, nation branding has become an important topic in research also, attracting an interdisciplinary interest, from areas such as 
marketing, international public relations, and public diplomacy, but also from schools of thought such as cultural studies and social constructivism.

The marketing approach (Anholt, 2003; Buhmann \& Ingenhoff, 2015; Fan, 2006; Hall, 1999; Kotler \& Gertner, 2002; Kotler et al., 1997; Marat, 2009; Olins, 2010; Papadopoulos \& Heslop, 2002; Will \& Porak, 2000) is functionalist, focusing on understanding nation branding in relation to commercial practices (Anholt, 2005; Olins, 2010). For instance, both nation brands and commercial brands are preoccupied with creating clear, simple, and different propositions, sometimes based on emotional qualities which can be symbolized verbally and visually (Olins, 2002, p. 145). In the case of nation branding, the emotional qualities are strongly connected to the national identity concept, strongly tied to nation branding.

On the other hand, the international public relations approach (Aronczyk, 2008; Dinnie, 2008; Dolea, 2015; Dolea \& Țăruș, 2009; Jordan, 2014; Kunczik, 1997, 2002; Szondi, 2008; Volcic, 2008, Wang, 2006a, 2006b, 2007; Zhang, 2007) insists on contextualizing the study of nation brand and analyzing, beside promotion campaigns, the contribution of political, cultural and economic agents in the nation branding practices. Public Relations are connected with nation branding because of the branding initiatives and also because they facilitate the coordination between the institutions and actors involved in the nation branding campaigns.

The public diplomacy perspective (Calabrese, 1996; Jansen, 2008; Gilboa, 2008; Mosco, 1996; Murdock \& Golding, 1991; Schiller, 1976; Szondi, 2008; Van Ham, 2001; Zhang, 2006) puts an emphasis on the fact that nation branding is a continuation of public diplomacy and a neoliberal project. In this globalized world, promoting the nation internationally is an effort driven by global capitalism. Public diplomacy is understood as the Government's use of soft power (Nye, 1990) in order to promote national interests to political actors, NGOs, and corporations. From a public diplomacy perspective, nation branding is a postmodern mutation of diplomacy and represents an evolution of diplomatic practice (Van Ham, 2001). Globalization is closely linked to the development of nation branding, while commercial neoliberalism privileges market relations in articulations of national identity (Jansen, 2008, p. 121). In this context, globalization has the power to articulate a country's aspirations for wealth, power and enhanced visibility.

Studies on nation branding also work in different paradigms, such as cultural studies or social constructivism. A key promoter of the cultural studies approach is Stuart Hall (1996), who operationalized Gramsci's concepts of ideology and hegemony in order to analyze the relationship between culture and power. A major premise of the cultural studies approach is to understand the meaning of discourses constructed by social actors in 
a specific cultural space. The focus is on the ways in which people interpret the dominant discourses about politics or national identity. Special attention is given to discourses and their manifestations, along with the analysis of textual representations.

The cultural studies approach on nation branding (Aronczyk, 2007; Bârdan \& Imre, 2012; Iordanova, 2007; Jansen, 2008, 2012; Kaneva, 2012, 2018; Kaneva \& Popescu, 2011, 2014; Kania-Lundholm, 2012; Surowiec, 2012; Volcic, 2008; Widler, 2007) insists on the discursive practices of the nation brand, in relation to elements such as national identity, culture, and diplomacy. Moreover, the nation brand can be analyzed as a discourse, and social acts are treated as texts. This leads to a constructivist approach as well, in which the model of textual representations (Barker, 2011; Kaneva, 2012) is dominant, while the production and reproduction of national identity discourses is closely analyzed.

The relationship between nation branding and national identity is a central issue in the cultural studies area (Aronczyk, 2007; Kaneva \& Popescu, 2008; Volcic, 2008). For Aronczyk (2007, p. 107), nation branding is a logical extension of a particular way that national identity has long been construed and communicated in time and space. If flags represent nations in war and diplomacy, brands and logos represent them in commerce and leisure. Aronczyk gives the example of Poland, whose nation branding campaign from 2002 changed the red-and-white flag, a stock symbol of national identity, into a red-and-white toy kite. The campaign was initiated by Poland's Ministry of Foreign Affairs and an advertising agency. The flag was the symbol of the country's political identity, while the kite was meant to bring a break from the past, a post-political national identity. The shift from political to "postpolitical" representations of national identity "appears to signal a change in the way we think about the idea of nation" (Aronczyk, 2007, p. 105). That is why the corporate and state interests intermingle in the process of branding a nation in commodity form. Hence, national identity is created through a specific branding and marketing process.

Another school of thought investigating the nation branding phenomenon is social constructivism. Constructivist approaches to nation branding are to be found in the public diplomacy field of research, leading to a multidisciplinary perspective. For Van Ham (2001), nation branding represents a neutral form of nation-building, which creates a well-functioning public sphere. In fact, this form of nation-building lacks "the deep-rooted and often antagonistic sense of national identity and uniqueness that can accompany nationalism" (Van Ham, 2001, p. 2). Therefore, nation branding can channel national sentiments into collective national identities, generating a sense of belonging. 
This article fills a gap in the literature by drawing attention to a multimodal approach to nation branding in transition countries. In Romania, research on nation branding (Dolea \& Țăruș, 2009; Dolea, 2015; Andrei, 2017, Popescu, 2007) relies on international public relations or marketing perspectives. Special attention is given to the legitimation strategies of public actors such as the Romanian Government in (re)branding the country (Dolea, 2015). Compared to other research, this article proposes a multidisciplinary approach, combining areas such as public diplomacy, cultural studies, and constructivism. The aim here is to explain that nation branding in transition countries share discursive practices to redefine and reconstruct national identity, taking into account different communication situations.

\section{Towards a social-semiotic approach of nation branding}

Brands can be regarded as particular signs, mental constructions that evoke a wide array of meanings (Danesi, 2006; Semprini, 1992). In this regard, the nation brand is an advertising sign and promoting the country image involves the appeal to signs and symbols which resonate with internal and external audiences.

A semiotic analysis of nation branding permits "an in-depth investigation of meanings employed in the campaigns to promote the country image to an international audience" (Cheregi, 2017, p. 29), it being an advertising sign and a semiotic artifact.

Research on nation branding from a semiotic perspective concentrates on spatial semiotics (Giovanardi, Lucarelli, Pasquinelli, 2013), on social semiotics (Thurlow \& Aiello, 2007), modality (Koller, 2008) and intertextuality (Graan, 2016). Thus, their "focus is not on the nation brand per se, but more on a nation brand's forms of manifestations, such as destination branding, country-of-origin effect, or city branding" (Cheregi, 2017, p. 29).

For example, Giovanardi et al. (2013) apply a semiotic framework to analyze three Italian territories (Montefeltro, Val di Cornia, Romagna), based on the constructs of syntax, semantics and pragmatics. By following an interpretive approach, their study shows that each place brand is characterized by a specific level of integration ('symbiosis') between functional and representational dimensions. Giovanardi et al. (2013) propose the concept of brand ecology in order to conceptualize the interrelation between place brands' functional (syntax) and representational (semantics) dimensions.

Another study about the semiotic explorations of nation branding is that of Thurlow and Aiello's (2007), examining how airlines are linked to national identity concerns. Drawing on a social semiotic approach, based on Kress and van Leeuwen (2001), they examined 561 different airline tailfin designs as visual genre, revealing how the global-local binary may be managed 
semiotically. Thurlow and Aiello (2007, p. 337) show that globalization is typically invoked as a discursive resource to explain and justify the ongoing reorderings of global capitalism. In this particular case, visual discourse works to reinscribe or reproduce patterns of economic exchange, because "just as globalism keeps reconfiguring itself, so too it seems the global semioscape is constantly being refashioned" (Thurlow \& Aiello, 2007, p. 338).

In order to see how city brands are encoded in different semiotic modes, Koller (2008) proposes a comparative study. The study proves that "cities have been reconceptualized as corporate brands as far as their nature allows," but "branding practices and discourses originating from the corporate sphere can only be transferred in parts" (Koller, 2008, p. 446). Therefore, citizens have been defined as customers and councils as service providers. Because of the global competition between cities, the appropriation of corporate discourses (branding) redefines and depoliticizes the relationship between council and citizens.

On the other hand, recent research (Breman \& Wilson, 2016; Burdick, 2016; Del Percio, 2016; Graan, 2016; Kelly-Holmes, 2016; Moore, 2016; Woolard, 2016) focus on nation branding as semiotic resources and on essentialized discourses around language and national identity. For instance, Andrew Graan (2016) analyzes the forms of metasemiotic regimentation in state-sponsored nation branding project for the Republic of Macedonia, from the perspective of communication and publicity as semiotic processes. In this particular context, nation branding and its attendant forms of brand management are understood as "a set of metapragmatic practices that aim to regiment public speech to define what counts as permissible public communication" (Graan, 2016, p. S78).

In fact, in the "Macedonia Timeless" campaign, nation branding works on numerous communicative levels - it serves to promote the country as a tourist or business destination and presents Macedonia as a fairytale literally coming to life. The results show that "the language of nation-branding advertisements often sounds the same" and "the logos and slogans, excepting difference in country name, appear interchangeable" (Graan, 2016, p. S86).

This leads further to a discussion about the economic logic of nation branding, connected to the conditions of finance capitalism, revealing the multilayered politics inherent to nation branding as a state pursuit. The relationship between nation branding and neoliberal commercialism will be explored later in the analysis section, focusing on social semiotic analysis of two governmental campaigns aiming to promote Romania's and Moldova's country image on the international stage. 


\section{Nation branding in Romania and Moldova}

Generally, in transition countries, there are similarities regarding the promotion of the country image, because of the constant need to reconfigure national identity by dissociating from the communist past (Kaneva, 2011). This is also the case with Romania and Moldova, which used the nation brand instrument in order to build their credibility, after the fall of the communist regime in 1989. In fact, "country branding is particularly relevant for developing countries in their struggle to define their political, economic and social roles" (Florek \& Conejo, 2007, p. 53).

Since 1996, the Romanian Government has started to promote Romania's country image overseas, and one of the first initiatives was the launch of the "Eternal and fascinating Romania" project. Nevertheless, only since 2005 has the "theme of Romania's country image been the object of an institutionalization process" (Beciu, 2011, p. 110), so the Government assumes responsibility for promoting the country internationally, working with consultancy agencies in order to initiate campaigns such as Romania Land of Choice (2009) and Explore the Carpathian Garden (2010). The last one generated a reaction from the media, which started to criticize the Government for its lack of professionalism. Moreover, nation branding is not just a concept, being also a type of public issue (Cheregi, 2015, p. 296) which "passes from the area of institutional and expertise discourses into the area of the public sphere, and generally, in the public discourses, including the quotidian life" (Beciu, 2013, p. 43).

Romania's first branding activities at a governmental level were more isolated actions that integrated communication campaigns (Dolea \& Țăruș, 2009). Put simply, the first approaches "have promoted tangible objects: places to visit in Romania, food, and only after 2005 appeared integrating concepts to present a more complex picture of the country and also to embrace customs, traditions, theatre plays and documentary films" (Dolea \& Țăruș, 2009, p. 84).

Currently, the Agency for Tourism in the Republic of Moldova is responsible for Moldavian nation branding projects. Since the collapse of the Iron Curtain in 1991, Moldova has become a "nationalizing nation" (Brubaker, 1996), with state formation preceding nation building. In this context, "tourism is considered to be a valuable tool to project perceived conceptualizations of the nation, its history, identity and the national territory" (Posch, 2015, p. 163).

In 2006, the Moldavian Government launched the Moldova Discover Us campaign, with a new brand logo in the shape of a cube. The concept was presented at the First International Conference Promoting Moldavia, but it 
seems that the campaign was not implemented and "the new brand initiative has been unexpectedly placed 'on hold'" (Florek \& Conejo, 2007, p. 57).

In 2013, Lonely Planet declared Moldova as Europe's least visited country according to a Traveler's Choice poll (Pettersen, 2013). Put simply, Moldova is the second off-the-beaten-path destination in the world, according to Lonely Planet. In this context, in 2014, the Agency for Tourism in the Republic of Moldova launched a new brand campaign, entitled Discover the Routes of Life, focusing on a complex symbol of national culture, inviting tourists to follow a path towards new discoveries, through hospitality, history, wine, gastronomy and Moldavian traditions (AGEPI, 2014). The advertising spot was promoted on the Euronews channel, focusing on destination branding. More recently, in 2016, the Discover the Routes of Life concept was presented at IMEX Frankfurt, dedicated to MICE (Meetings, Incentives, Conferences and Exhibitions) tourism. Here, the focus was mainly on wine incentives, in order to attract professionals to visit the Republic of Moldova for the cultural experience, competitive prices and rich vineyards.

\section{RESEARCH METHODS}

In order to explore the differences and similarities of two governmental campaigns aiming to promote Romania's and Moldova's country image on the international stage, the research draws on a multimodal approach (ledema, 2003; Kress \& Van Leeuwen, 1996; Van Leeuwen, 2001), in order to highlight the importance of image, sound and text as semiotic resources in the discursive configuration of Romania's and Moldova's nation brands, comparatively.

Special attention is given to the analysis of logos, websites and videos, comprising different communication situations used to create meaning in the tourism campaigns. The corpus is heterogeneous, based on two nation branding campaigns initiated by the Government: Discover the Place Where You Feel Reborn (Romania, 2014), Discover the Routes of Life (Moldova, 2014), along with the official websites (www.romania.travel and www.moldova.travel).

This paper investigates how elements of neoliberal ideology are addressed in two governmental campaigns comparatively, considering the "marketization of public discourse" (Fairclough, 1993). In so doing, the research questions underlying the social semiotic analysis are:

RQ1: What are the main semiotic resources employed in the two nation branding campaigns, comparatively, and how are they organized?

RQ2: What types of national identity discourses are employed in the nation branding campaigns (symbols, myths, language)? 
RQ3: How are elements of neoliberal ideology addressed in the two governmental campaigns, comparatively?

The social semiotic perspective (Bell, 2001; Hodge \& Kress, 1988; Jewitt \& Oyama, 2001; Jewitt \& Van Leeuwen, 2001; Kress \& van Leeuwen, 2006; Van Leeuwen, 2001, 2005) derives from the work of Michael Halliday and focuses on the uses of semiotic systems in social practice. The key term is "semiotic resource," preferred instead of "sign" because it avoids the impression that "what stands for it is somehow pre-given, and not affected by its use" (Van Leeuwen, 2005, p. 3). In this regard, the meanings expressed by speakers are first and foremost social. An iconicity is always an act of perception, while symbolism relies on inference and judgment (Hodge \& Kress, 1988).

The article proposes a methodological framework that employs a set of categories from social semiotics: semiotic resources, modality (high/ medium/low), contact (offer/demand) and mode.

First of all, semiotic resources are the products of cultural histories and the cognitive resources we use to create meaning in the production and interpretation of visual and other messages (Jewitt \& Oyama, 2001, p. 136). Resources are also signifiers, observable actions and objects that have a theoretical semiotic potential constituted by all their past uses and all their potential uses. Visual modality refers to the

"degreeto which certain means of pictorial expression (color, representational detail, depth, tonal shades, etc.) are used. Each of these dimensions can be seen as a scale, running from the absence of any rendition of detail to maximal representation of detail, or from the absence of any rendition of depth to maximally deep perspective" (Kress and van Leeuwen, 2006, p. 256).

Given the sensory coding orientation, based on degrees of color saturation, modality has three values: 'high' (image uses highly saturated colors naturalistically), 'medium' (image uses less saturated colors) and 'low' (image is monochrome).

Another important category is contact, establishing a relationship between the visual and the viewer/the audience. According to Kress and van Leeuwen (2006), there is a distinction between 'demand' and 'offer' pictures. For instance, in 'demand' pictures, people represented in the image symbolically demand something from the viewer. Facial expressions and gestures are important indicators to see exactly what they 'demand.' On the other hand, the 'offer' visuals are based on the fact that an 'offer of information' is made (Jewitt \& Oyama, 2001, p. 146). 
The social semiotic approach to visuals (Bell, 2001; Jewitt \& Oyama, 2001; Kress \& Van Leeuwen, 1996; Van Leeuwen, 2001) focuses on the interpersonal semiosis of images, where images may be analyzed without any recourse to the verbal or written information that may accompany them (Jewitt \& Van Leeuwen, 2001, p. 6).

Another key term in social semiotics is semiotic landscape or "the place of visual communication in a given society" that can only be understood in the context of "the range of forms and modes of public communication available in that society and, on the other hand, their uses and valuations" (Kress \& van Leeuwen, 2006, p. 35). The features of a landscape only make sense in the context of their environment and the history of its development. Further, the realities of the semiotic landscape are brought about by social, cultural and economic factors. The semiotic modes complete the landscape, being shaped both by the intrinsic characteristics and potentialities of the medium and by the requirements, histories and values of societies and their cultures.

These analytical instruments are applied to examine the discursive construction of nation branding in two governmental campaigns, comparatively. We will see how meaning is constructed in different communication situations, starting with campaign logos, slogans, typography, and then continuing with a social semiotic analysis of the campaign websites. Last, but not least, we will examine the tourism videos, taking the frame as a unit of analysis.

\section{RESULTS}

If we look at the two campaign logos comparatively (Figure 1), one can notice that both logos are polysemous, leading to multiple significations and appeal to cultural symbols. The green color from Explore the Carpathian Garden campaign is, in fact, a metonymic resource for iconically representing nature, being also an icon and symbol of Romanian nature attractions. Conversely, the logo from Discover the Routes of Life campaign is a metonymic image of Moldavian wine-making traditions, being an icon and symbol of grape vines. If in the Romanian campaign the focus is on destination branding (Kotler et al., 1993; Pike, 2009), in the Moldavian campaign the focus is mainly on the country-of-origin effect (Schooler, 1965), emphasizing two of the most important forms of manifestations of the country as a brand.

Both slogans (Explore the Carpathian Garden, Discover the Routes of Life) are built on a "call-to-action" technique, borrowed from successful marketing case studies. Overall, the techniques used to promote the country image are 
inspired by marketing, so the nation branding phenomenon is linked to the "marketization of public discourse" (Fairclough, 1993).

The green leaf logo from Explore the Carpathian Garden campaign was intensely criticized by Romanian bloggers, because of its resemblance to the logo of British company Change Transport. The information first appeared on a blog, with the headline "Discover the differences between the two images. The Ministry of Tourism is stealing images for the nation brand logo" (Dorombach, 2010). The Romanian media has rapidly disseminated this information, debating about the necessity of a country brand. The Tourism Minister Elena Udrea was criticized for the nation branding campaign, and several articles in the media mentioned "Elena Udrea's leaf."
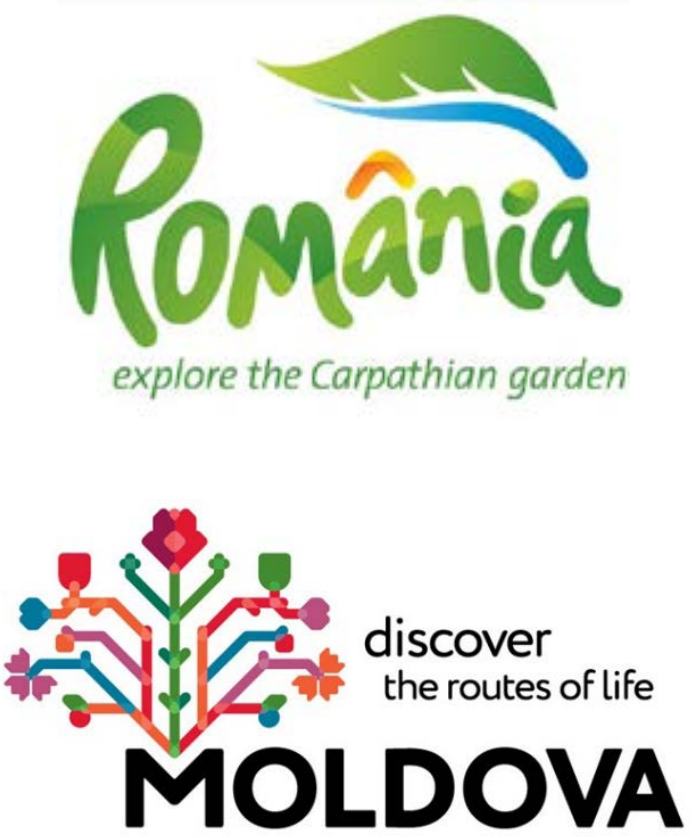

Figure 1. Explore the Carpathian Garden (2010) and Discover the Routes of Life (2014) campaign logos

The typography of the logos serve as a semiotic resource with its own meaning potential, so "rather than acting as a naturalized conduit for the communication of a verbal narrative, the typographical elements have become an integral part of the narrative itself, a semiotic resource" (Serafini \& Clausen, 2012, p. 5). In the Romanian logo, one can notice a medium modality, with natural colors and a rounded font. As for the Moldavian logo, 
the colors are highly saturated, leading to a high modality. The font is bold, drawn in black, symbolizing the fertile soil from which the tree of life grows. The Moldovan five petal rose is placed in the center, at the end of the grape vines, being a national symbol.

The Romania Travel homepage (http://www.romania.travel/, accessed on June 10, 2018) offers an interactive experience (Figure 3), with a horizontal user journey and a "carousel" presenting key touristic objectives and cultural symbols (Capșa House, the meeting place of many Romanian intellectuals of the nineteenth century, Sibiu, the European Capital of Culture in 2007, Brașov's coat of arms, citadels, the Merry Cemetery, and Christmas traditions). The modality is medium and one can notice authentic photographs of touristic objectives. The text is personal ("My view of Romania"), inviting the tourists to create their own travel experiences.

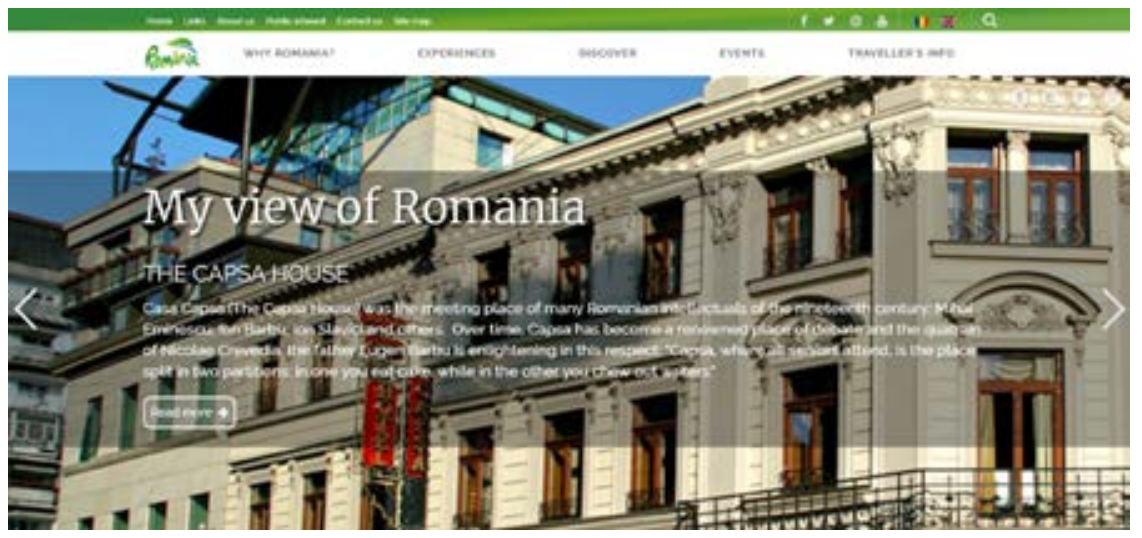

Figure 2. Romania Travel homepage (http://www.romania.travel/, accessed on June 10, 2018)

On the other hand, the Moldova Travel homepage (http://www.moldova. travel/, accessed on June 10,2018) offers a static user experience (Figure 3), and the user journey is vertical, similar to personal blogs. The modality is high and one can notice highly saturated colors in the background image sending to an autumn landscape. The button is a direct call-to-action ("Subscribe"), creating a connection with tourists interested to discover Moldova. 


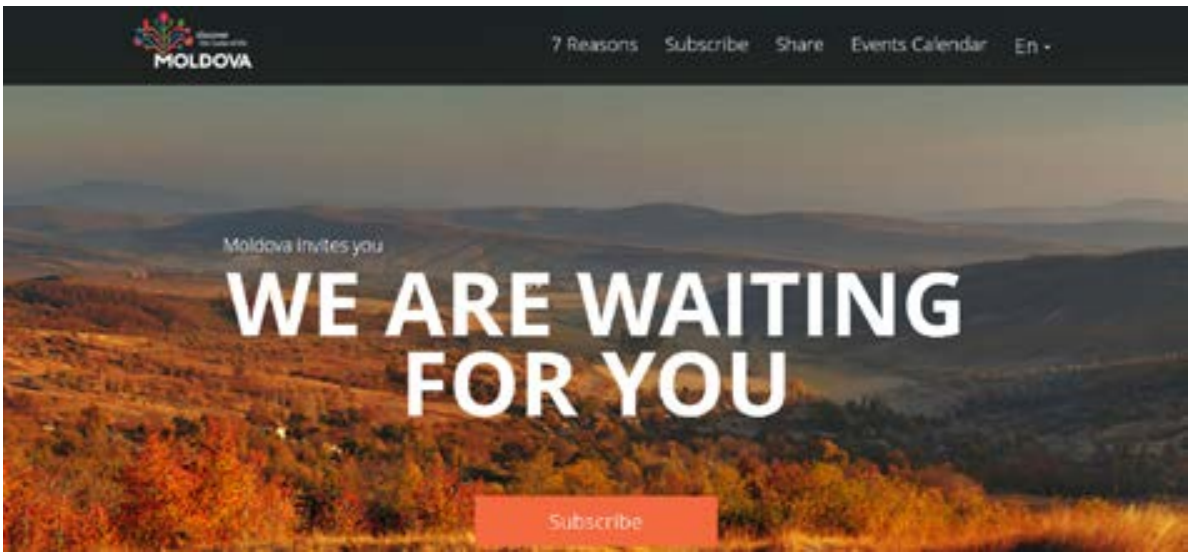

Figure 3. Moldova Travel homepage (http://www.moldova.travel/, accessed on June 10,2018 )

The analysis of the tourism campaigns shows that both videos make demands on the viewers. The Discover the Place Where you Feel Reborn campaign was launched in 2014 and is part of the "Explore the Carpathian Garden" governmental campaign. The story follows a man passing through different places in Romania and we listen to a narrator describing his own experiences:

"Here, in these places is where I wish I was born. Every time I discover the traditions and the culture from these places I feel alive, I feel reborn. Romania, Explore the Carpathian Garden".

The commercial starts with a frame showing a young man with long hair drinking water from a traditional clay pot. He is wearing a backpack and travels to different places in Romania. Next, the visuals show a frame with the man visiting Voroneț monastery, one of the painted churches of Moldavia listed in UNESCO's list of World Heritage sites. The frescoes at Voroneț feature an intense shade of blue known in Romania as "Voroneț blue." The young man is touching the wall of the monastery featuring the "Last Judgement" theme. In the next frame, we can see a nun playing a semantron right in front of the monastery.

Further, the man is making a traditional Romanian clay pot, with the help of a village lady. The next frames present one of the most important Romanian cultural symbols, Brâncuși's Endless Column. The column is linked to the infinite sacrifice of the Romanian soldiers during the First World War. Besides this, the Endless Column is also the axis mundi or the axis of the world, expressing a point of connection between Heaven and Earth. This space serves as a microcosm of order. For Mircea Eliade (1991, p. 39), "every 
microcosm, every inhabited region has a Centre, that is to say, a place that is sacred above all." The rhomboid shapes of the column represent the idea of infinity, connecting Heaven with Earth. In this commercial, the young man is touching the Endless Column, a sculpture linked to the mythical past and distant cultural memory of the Romanian folkloric tradition.

The tourism spot shows the "Dracula castle" from a panoramic view. Therefore, Dracula's myth is appealing to foreign audiences by interpolating neoliberal commercialism. In the particular situation of Romania, Bârdan and Imre (2012) consider that we are dealing with "vampire branding," because of the multiple uses of the Dracula story in the promotion campaigns. A possible explanation for using the Dracula story in nation branding campaigns is that they aim to attract Western audiences. Thus, the myth is not representative for Romanian people, even though foreigners are more familiar with the bloodthirsty Vlad Tepeș, because of Bram Stoker's successful novel. An interesting fact is that the young man is charmed by beautiful Romania women when discovering the castle. They symbolize feminine mythical creatures in Romanian mythology, known as "iele"1. Similar to the samodivas in Bulgaria; the Romanian fairies have great seductive power over men and magic skills. They are also known as singing and dancing fairies of the night.

In the Discover the Place Where You Feel Reborn campaign, national identity discourses are constructed by appealing to traditions (a man creating a traditional clay pot, the presence of the Romanian "evil fairies" known as "iele"), religion (painted monasteries, a nun playing the semantron), culture (Brâncuși's Endless Column) and architecture (the medieval Sighișoara, Bran Castle). Elements of the neoliberal ideology are addressed by commercial discourses ("Romania, Explore the Carpathian Garden"), reinforcing the cliché representation of what capitalist economies offer.

As for the Discover the Routes of Life campaign, it was launched in 2014 in the Republic of Moldova, as a response to Lonely Planet's declaration that Moldova is Europe's least visited country. The concept was based on Moldova's long winemaking tradition, being one of the top wine-producing countries in the world. Visual representations of Moldovan heritage and history are not dominant, even though the video features some key touristic objectives.

The video starts with a frame showing a car passing through a nature scene with red, green and yellow leaves. In the following frame, the car stops and the driver starts a short dialogue with the tourist: "The driver: It will take an hour, maybe two. The tourist: Well, l'll just go, l'll go for a walk then". As in the Discover the Routes of Life campaign, the story follows a man passing through different places in Moldova, discovering pristine places and one of the most important historical sites, Orheiu Citadel, known for the foundation walls of the Tatar-Mongol baths. 
Next, the tourist sees a man and a woman on an ox cart, leading to a famous picture with the same name, made by the Romanian painter Nicolae Grigorescu. The appeal to religion and Moldavian monasteries is very subtle, showing an image of a Russian Orthodox Church in the background of the image. A keyframe is the one in which the man stops near a grapevine and tastes grapes, a symbol of Moldavia's new tourism concept. A Moldavian family invites the tourist to join them, although initially, the Moldovan man has a suspicious look. The focus is on the hospitality of Moldovans, on gastronomy (stuffed vine leaves with polenta) and on traditional music and dance.

In the end, the voiceover turns directly to the viewers to visit Moldova: "Find yourself in the heart of the countryside. Rediscover what it means to be the most welcomed guest. Visit the authentic Moldova". The commercial discourses are to be noticed here, with a strong focus on rural Moldova and hospitality.

In the Discover the Routes of Life campaign, national identity discourses are constructed by appealing to nature (a tourist walking on pristine landscapes, Moldovan grapes as a symbol of wine-making traditions); history (Orheiul Vechi citadel); traditions (Moldavian songs and dance, traditional food), religion (an Orthodox church in a frame), hospitality (Moldavians are presented as being friendly with foreigners), and architecture (the Moldavian rural houses).

Elements of neoliberal ideology are addressed by commercial discourses ("Discover the routes of life," "Be our guest," "Visit the authentic Moldova"), also reinforcing the cliché representation of what capitalist economies offer.

\section{DISCUSSION AND CONCLUSION}

The results show that a social semiotic analysis of Eastern European nation branding campaigns help us understand how different modes of the nation are constructed in the public space through tourism promotion and marketing. Discover the Place Where You Feel Reborn (Romania, 2014) and Discover the Routes of Life (Moldova, 2014) are both semioscapes, understood as "globalizing circulation of symbols, sign systems and meaningmaking practices" (Thurlow \& Aiello, 2007). Therefore, the semiotic resources circulate between different scopes, leading to different understandings of national and cultural symbols.

Both of the nation-branding campaigns appeal to two of the most critical forms of manifestations of the country as a brand. If, in the Romanian campaign, the focus is on destination branding (Kotler, Haider \& Rein, 1993; Pike, 2009), presenting mainly touristic objectives, in the Moldavian campaign the focus is mainly on a country-of-origin effect (Schooler, 1965), revealing the Moldavian grape vines tradition. The campaign logos are polysemous, leading 
to multiple significations in the semioscape. The logo from the Explore, the Carpathian Garden campaign, is a semiotic resource representing nature, being an icon and symbol of Romanian nature attractions. Conversely, the logo from the Discover the Routes of Life campaign is a metonymic image of Moldavian wine-making traditions, being an icon and symbol of grape vines. Both slogans (Explore the Carpathian Garden, Discover the Routes of Life) are built on a "call-to-action" technique, borrowed from successful marketing case studies, leading to the "marketization of public discourse" (Fairclough, 1993).

The social semiotic analysis of the tourism campaign websites shows that the Romania Travel homepage (http://www.romania.travel/, accessed on June 10, 2018) offers an interactive experience, with a horizontal user journey and medium modality, while the Moldova Travel homepage (http://www. moldova.travel/, accessed on June 10, 2018) offers a static user experience and a high modality, with a vertical user journey, similar to personal blogs.

Both campaign videos make demands to the viewers, inviting them to discover a life experience. The Discover the Place Where You Feel Reborn campaign is based on a first-person narrator, presenting a man with a long hair, traveling through different places in Romania, discovering Bukovina painted monasteries, traditional clay pots, Brâncuși's Endless Column and Bran Castle. In the Discover the Routes of Life campaign, the story follows a man discovering pristine Moldavian places and one of the most important historical sites, Orheiu Citadel, known for the foundation walls of the Tatar-Mongol baths.

Nation branding is also connected to national identity discourses, especially in the particular case of post-communist countries such as Romania or Moldova. The results show that in Discover the Place Where You Feel Reborn campaign, national identity discourses are constructed by appealing to traditions (a man creating a traditional clay pot, the presence of the Romanian "evil fairies" known as "iele"), religion (painted monasteries, a nun playing the semantron), culture (Brâncuși's Endless Column) and architecture (the medieval Sighișoara, Bran Castle). On the other hand, in Discover the Routes of Life campaign, national identity discourses are constructed by appealing to nature (a tourist walking on pristine landscapes, Moldovan grapes as a symbol of wine-making traditions); history (Orheiul Vechi citadel), traditions (Moldavian songs and dance, traditional food), religion (an Orthodox church in a frame), hospitality (Moldavians are presented as being friendly with foreigners), and architecture (the Moldavian rural houses).

Elements of the neoliberal ideology are addressed in both tourism campaigns ("Romania, Explore the Carpathian Garden," "Discover the routes of life," "Be our guest," "Visit the authentic Moldova"), reinforcing the cliché representation of what capitalist economies offer. 
Overall, this study proves Kaneva and Popescu's (2011, p. 201) claim that "national identity is appropriated for the purposes of neoliberal globalization." As we have seen in the Results section, both nation branding campaigns employ semiotic resources that circulate between different scopes, leading to multiple understandings of national and cultural symbols.

The question that emerges here is whether there is an oppressive side to branding national identities. For Kaneva and Popescu (2014, p. 509), discourses of branded nationhood have the power to reproduce hierarchies of othering. Nation branding also becomes an instrument used in the construction of alterity. The effort to fight against stereotyping is also connected to the nation brand, launching a debate about stereotypes about a nation that influence the country image, or about the country image that leads to further stereotypization. Future studies should consider crosscultural approaches between transition countries, in order to see whether there is a significant resemblance between different semioscapes, trying to detach themselves from a communist past.

The nature of nationhood is also changing in the age of globalization, marketization, and mediatization. In this context, nation branding should also be understood in the contemporary fake news phenomenon, relying on the achievement of the sense of belonging through soft power (Nye, 2004) practices. The "imagined community" (Anderson, 1991) is now reconfigured to the logics of fabricated content, which affects nation branding projects as well. The question that should be addressed here is: how does the aim to generate maximum profit affect destination branding or the country-of-origin effect. Future research should investigate this further.

\section{Notes}

"lele" is the name of "evil fairies" in Romanian mythology. They are mentioned in old Romanian folktales and legends and they have been a constant source of inspiration for many Romanian writers.

\section{References}

Academic Dictionaries and Encyclopedias. (n.d.). Movement for the unification of Romania and Moldova. Retrieved 28 August, 2018, from http://enacademic.com/dic.nsf/enwiki/11759632

AGEPI. (2014). "Tree of life" - The New Touristic Brand of the Republic of Moldova! Retrieved 28 August, 2018, from http://agepi.gov.md/en/ news/\%E2\%80\%9Ctree-life\%E2\%80\%9D-\%E2\%80\%93-new-touristicbrand-republic-moldova

Anderson, B. (1991). Imagined Communities: Reflections on the Origin and Spread of Nationalism. USA: Courier Companies, Inc. 
Anholt, S. (2003). Brand New Justice: The Upside of Global Branding. Oxford, UK: Butterworth-Heinemann.

Andrei, A.-G. (2017). The impact of nation branding campaigns on country image. Case Study: Romania. Management \& Marketing. Challenges for the Knowledge Society, 12(2), 222-236. https://doi.org/10.1515/ mmcks-2017-0014

Aronczyk, M. (2007). New and improved nations. Branding national identity. In C. Calhoun \& R. Sennett, Practicing Cultures (pp. 105-128). New York: Routledge.

Aronczyk, M. (2008). "Living the brand": nationality, globality and the identity strategies of nation branding consultants. International Journal of Communication, 2, 41-65.

Bârdan, A., \& Imre, E. (2011). Vampire Branding. Romania's Dark Destinations. In N. Kaneva, Branding Post-Communist Nations: Marketizing National Identities in the "New Europe." London: Routledge.

Barker, C. (2011). Cultural Studies: Theory and Practice (4th ed.). London: Sage Publications.

Baudrillard, J. (2001). Selected Writings. Stanford, California: Stanford University Press.

Beciu, C. (2011). Sociologia Comunicării și a Spațiului Public [Sociology of Communication and Public Space]. Iasi: Polirom.

Beciu, C. (2013). Discursive representations of migrants in political talkshows in Romania. Revista Romana de Sociologie [Romanian Journal of Sociology], (1-2), 41-62.

Bell, P. (2001). Content analysis of visual images. In T. Van Leeuwen \& C. Jewitt, Handbook of Visual Analysis (pp. 10-34). Thousand Oaks, CA: Sage Publications.

Bockman, J. (2013). Neoliberalism. Contexts, 12(3), 12-14. https://doi. org/10.1177/1536504213499873

Brennan, S. C., \& Wilson, J. C. (2016). The indexical reordering of language in times of crisis: Nation, region, and the rebranding of place in Shetland and Western Ireland. Signs and Society, 4(S1), 106-134.

Brubaker, R. (1996). Nationalism Reframed: Nationhood and the National Question in the New Europe. Cambridge, UK: Cambridge University Press.

Buduru, B., \& Popa, D. (2006). Moldova: Country at a crossroads. Transitions, 45(2), 171-190.

Buhmann, A., \& Ingenhoff, D. (2015). The 4D Model of the country image: An integrative approach from the perspective of communication management. The International Communication Gazette, 77(1), 102-124.

Burdick, C. (2016). Branding the Alsatian oxymoron: The production of ambivalent identity. Signs and Society, 4(S1), 163-186.

Calabrese, A. (1997). Creative destruction? From the welfare state to the global information society. Javnost-The Public, 4(4), 7-24. 
Cheregi, B. -F. (2017). Nation branding in Romania after 1989: A cultural semiotic perspective. Romanian Journal of Communication and Public Relations, 19(1), 27-49.

Cheregi, B. -F. (2018). Nation branding in post-communist Romania. A semiotic approach. Bucharest: comunicare.ro.

Crompton, J. L. (1979). An assessment of the image of Mexico as a vacation destination and the influence of geographical location upon that image. Journal of Travel Research, 17(4), 18-23.

Danesi, M. (2006). Visual Semiotics. The Encyclopedia of Language and Linguistics (2nd ed.). Amsterdam: Elsevier.

Del Percio, A. (2016). Nation brands and the politics of difference. Signs and Society, 4(S1), 1-26.

Dinnie, K. (2008). Nation Branding. Concepts, Issues, Practice. Oxford: Elsevier. Dolea, A. (2015). Twenty Years of (Re)Branding Post-Communist Romania Actors, Discourses, Perspectives (1990-2010). Bucharest: Institutul European.

Dolea, A., \& Jăruş, A. (2009). Branding România: Cum (ne) promovăm imaginea de țară [Branding Romania: How we promote (our) country image]. Bucharest: Curtea Veche.

Dorombach. (2010). Descoperiți diferențele dintre cele două imagini [Discover the differences between the two images]. Retrieved 28 August, 2018, from http://www.piticu.ro/descoperiti-diferentele-din-cele-doua-imagini.html

Eliade, M. (1991). Images and Symbols. Princeton N.J.: Princeton University Press.

Fairclough, N. (1993). Critical discourse analysis and the marketisation of public discourse: The universities. Discourse \& Society, 4(2), 133-168.

Fan, Y. (2006). Branding the nation: What is being branded? Journal of Vacation Marketing, 12(1), 5-14.

Florek, M., \& Conejo, F. (2007). Export flagships in branding small developing countries: The cases of Costa Rica and Moldova. Place Branding and Public Diplomacy, 3(1), 53-72.

Gilboa, E. (2008). Searching for a theory of public diplomacy. The Annals of the American Academy of Political and Social Science, 616(1), 55-77.

Giovanardi, M., Lucarelli, A., \& Pasquinelli, C. (2013). Towards brand ecology: An analytical framework for interpreting the emergence of place brands. Marketing Theory, (13), 365-383.

Graan, A. (2016). The nation brand regime: Nation branding and the semiotic regimentation of public communication in contemporary Macedonia. Signs and Society, 4(1), 70-102.

Hall, S. (1996). Gramsci's relevance for the study of race and ethnicity. In D. Morley \& K.

Chen, Critical Dialogues in Cultural Studies (pp. 411-440). London: Routledge. Hodge, R., \& Kress, G. (1988). Social Semiotics. Cambridge, UK: Polity Press. ledema, R. (2003). Multimodality, resemiotization: Extending the analysis of discourse as multi-semiotic practice. Visual Communication, 2(1), 29-57. 
Iordanova, D. (2007). Cashing in on Dracula: Eastern Europe's hard sells. Framework, 48(1), 46-63.

Jansen, S. C. (2008). Designer nations: Neo-liberal nation branding - Brand Estonia. Social

Identities, 14(1), 121-142.

Jansen, S. C. (2012). Redesigning a nation. Welcome to Estonia, 2001-2018. In N. Kaneva,

Marketizing National Identities in the "New" Europe. New York: Taylor \& Francis.

Jenkins, H. (2006). Convergence Culture: Where Old and New Media Collide. New York:

New York University Press.

Jewitt, C., \& Oyama, R. (2001). Visual meaning: A social semiotic approach. In T. Van Leeuwen \& C. Jewitt (Eds.), Handbook of Visual Analysis (pp. 134156). Thousand Oaks, CA: Sage Publications.

Jewitt, C., \& Van Leeuwen, T. (2001). Handbook of Visual Analysis. Thousand Oaks, CA:

Sage Publications.

Jordan, P. (2014). Nation branding: A tool for nationalism? Journal of Baltic Studies, 45(3), 283-303.

Kaneva, N. (2011). Toward an agenda for critical research. International Journal of Communication, 5, 117-141.

Kaneva, N. (2012). Branding Post-Communist Nations: Marketizing National Identities in the "New" Europe. London: Routledge.

Kaneva, N. (2018). Simulation nations: Nation brands and Baudrillard's theory of media. European Journal of Cultural Studies, 1-18. https://doi. org/10.1177/0267323116670808

Kaneva, N., \& Popescu, D. (2011). Nation branding in post-Communist Romania and Bulgaria. International Journal of Cultural Studies, 14(2), 191-207.

Kaneva, N., \& Popescu, D. (2014). "We are Romanian, not Roma": Nation branding and postsocialist discourses of alterity. Communication, Culture \& Critique, (7), 506-523.

Kelly-Holmes, H. (2016). Constructing and disputing brand national identity in marketing discourse. Signs and Society, 4(S1), 51-67.

Koller, V. (2008). "The world in one city": Semiotic and cognitive aspects of city branding.

Journal of Language and Politics, 7(3), 431-450.

Kotler, Philip, \& Gertner, D. (2002). Country as a brand, product, and beyond: A place marketing and brand management perspective. The Journal of Brand Management, 9(4-5), 249-261.

Kotler, P., Haider, D., \& Rein, I. (1993). Marketing Places. New York: The Free Press.

Kress, G., \& Van Leeuwen, T. (2006). Reading Images: The Grammar of Visual Design. London: Routledge. 
Kunczik, M. (1997). Images of Nations and International Public Relations. New Jersey: Lawrence Erlbaum Associates.

Kunczik, M. (2002). Globalization: News media, images of nations and the flow of international capital with special reference to the role of rating agencies. The Journal of International Communication, 8(1), 39-79.

Marat, E. (2009). Nation Branding in Central Asia: A New Campaign to Present Ideas about the State. London: Routledge.

Moore, R. (2016). Rebranding Belfast: Chromatopes of (Post-Conflict). Signs and Society, 4(S1), 138-159.

Mosco, V. (1996). The Political Economy of Communication: Rethinking and Renewal. London: Sage Publications.

Murdock, G., \& Golding, P. (1991). Culture, communications and political economy. Mass media and society. Mass Media and Society, 2, 15-32.

Nye, J. (1990). The changing nature of world power. Political Science Quarterly, 105(2), 177-192.

Olins, W. (2002). Branding the nation - the historical context. Journal of Brand Management, 9(4-5), 241-248.

Olins, W. (2010). Brandingul de națiune [Nation Branding]. In Ștefan Liuțe (Trans.), Despre brand [On Brand]. Bucharest: comunicare.ro.

Papadopoulos, N., \& Heslop, L. (1993). Country equity and country branding: Problems and prospects. Journal of Brand Management, 9(4-5), 294-314.

Papadopoulos, N., \& Heslop, L. (2002). Country equity and country branding: Problems and prospects. Journal of Brand Management, 2(1), 294-314.

Pettersen. (2013). Moldova: Embracing its status as Europe's least visited country. Retrieved 28 August, 2018, from Lonely Planet, https:// www.lonelyplanet.com/moldova/travel-tips-and-articles/moldovaembracing-its-status-as-europes-least-visited-country/40625c8c-8a115710-a052-1479d277bb3a

Popescu, G. (2017). Brandul de oraș ca vector al brandului de țară. Sibiu Capitală Europeană a Culturii [The City Brand as a Country Brand Vector. Sibiu - European Capital of Culture]. Bucharest: Tritonic.

Posch, E. (2015). Negotiating the nation in tourist historiography from the Republic of Moldova. Revue d'études Comparatives Est-Ouest, 46(1), 161-184. https://doi.org/10.4074/S0338059915001072

Roth, M., \& Romeo, J. (1992). Matching product category and country image perceptions: A framework for managing country-of-origin effects. Journal of International Business Studies, 23(3), 477-497.

Schiller, H. (1976). Communication and Cultural Domination. New York: International Arts and Sciences Press.

Schooler, R. (1965). Product bias in the Central American common market. Journal of Marketing Research, 2(4), 394-397.

Semprini, A. (1992). Le marketing de la marque: Approche sémiotique. Paris: Liaisons.

Serafini, F., \& Clausen, J. (2012). Typography as semiotic resource. Journal of Visual Literacy, 31(2), 1-16. 
Surowiec, P. (2012). Towards Corpo-nationalism: A Bourdieusian Study Exploring the Relationship Between Nation Branding and the Reproduction of Polishness (1999 - 2010) (PhD thesis). Bournemouth University, UK.

Szondi, G. (2007). The role and challenges of country branding in transition countries: The Central and Eastern European experience. Place Branding and Public Diplomacy, 3(1), 8-20.

Szondi, G. (2008). Public Diplomacy and Nation Branding: Conceptual Similarities and Differencies. Netherlands: Nederlands Institute of International Relations 'Clingendael'

Thurlow, C., \& Aiello, G. (2007). National pride, global capital: A social semiotic analysis of transnational visual branding in the airline industry. Visual Communication, 6(3), 305-344.

Van Ham, P. (2001). The rise of the brand state. The postmodern politics of image and reputation. Journal of Forreign Affairs, 80(5), 2-6.

Van Leeuwen, T. (2001). Semiotics and iconography. In T. Van Leeuwen \& C. Jewitt, Handbook of Visual Analysis (pp. 92-118). Thousand Oaks, CA: Sage Publications.

Varga, S. (2013). The politics of nation branding: Collective identity and public sphere in the neoliberal state. Philosophy and Social Criticism, 8(39)1-21.

Volcic, Z. (2008). Former Yugoslavia on the world wide web: Commercialization and branding of nation states. International Communication Gazette, 70(5), 495-413.

Volcic, Z. (2012). Branding Slovenia. "You Can't Spell Slovenia Without Love..." in N. Kaneva, Marketizing National Identities in the "New" Europe. New York: Taylor \& Francis.

Volcic, Z., \& Andrejevic, M. (2016). Commercial Nationalism: Selling the Nation and Nationalizing the Sell. USA: Palgrave MacMillan.

Wang, J. (2006a). Localising public diplomacy: The role of sub-national actors in nation branding. Place Branding, 2(1), 32-42.

Wang, J. (2006b). Managing national reputation and international relations in the global era: Public diplomacy revisited. Public Relations Review, 32(2), 91-96.

Widler, J. (2007). Nation branding: With pride against prejudice, place branding and public diplomacy. Place Branding and Public Diplomacy, 3(2), 144-150.

Will, M., \& Porak, V. (2000). Corporate communication in the new media environment: A survey of 150 corporate communication web sites. The International Journal of Media Management, 2(3-4), 195-201.

Woolard, K. A. (2016). Branding like a State: Establishing Catalan singularity at the Frankfurt Book Fair. Signs and Society, 4(S1), 29-48.

Zhang, J. (2006). Public diplomacy as symbolic interactions: A case study of Asian tsunami relief campaigns. Public Relations Review, 32, 26-32. 


\begin{abstract}
Abstrakt
Natura narodowości zmienia się $w$ dobie globalizacji, uprzemysłowienia i mediatyzacji. W tym kontekście naród budowany jest jako marka w celu przyciqgnięcia turystów i zwiększenia rozwoju gospodarczego. Szczególny przypadek brandingu narodu można znaleźć w Rumunii i Mołdawii, dwóch krajach, które zaczęły repozycjonować się po upadku komunizmu. W tym kontekście niniejszy artykuł koncentruje się na porównawczej analizie semiotycznej dwóch narodowych kampanii brandingowych zainicjowanych przez rzq̨dy Rumunii i Mołdawii: "Odkryj miejsce, w którym czujesz się odrodzony" (Romania, 2014) i "Odkryj drogi życia" (Moldova, 2014). W tym celu stosuje się podejście multimodalne (ledema, 2003; Kress \& Van Leeuwen, 1996; Van Leeuwen, 2001.), podkreślajqc znaczenie obrazu, dźwięku i tekstu jako zasobów semiotycznych w dyskursywnej konfiguracji narodowych marek Rumunii i Mołdawii. Szczególnq uwagę zwraca się na analizę logotypów, stron internetowych i filmów wideo, zawierajqcych różne sytuacje komunikacyjne, które majq znaczenie w kampaniach turystycznych. Artykuł analizuje, w jaki sposób elementy neoliberalnej ideologii zostały poruszone $w$ dwóch kampaniach rzqdowych, porównujq̨c je i biorq̨c pod uwage "urynkowienie publicznego dyskursu" (Fairclough, 1993).
\end{abstract}

Słowa kluczowe: branding narodu, kraje transformacji, analiza multimodalna, semiotyka społeczna, ideologia neoliberalna.

\title{
Biographical note
}

Bianca-Florentina Cheregi is an assistant lecturer at the College of Communication and Public Relations, National University of Political Science and Public Administration, Bucharest, Romania. She has a Ph.D. in Communication Science, and her areas of interest include nation branding, country image, migration, multimodal analysis, and aspects of visual semiotics in the digital era. She is currently a "Spiru Haret" fellow and a member of the Communication, Discourse, Public Issues Lab (CoDiPo), affiliated to the Center of Research in Communication. 